\title{
Detection of bovine herpesvirus type 1 and bovine ephemeral fever virus antigens in cattle lymph nodes using three immunological assays
}

\author{
S. M. Tamam, A. S. Abdel-Moneim \\ Department of Virology, Faculty of Veterinary Medicine, Beni-Suef University, Beni-Suef. Egypt
}

\begin{abstract}
Lymph nodes (Ln) are the preferred samples for virus isolation and detection. In the present study, carcass and visceral $\mathrm{Ln}$ of apparently healthy cattle were screened for the presence of bovine herpes virus type 1 (BHV-1) and bovine ephemeral fever virus (BEFV) antigens. A total of 198 Ln (114 carcasses Ln and 84 visceral Ln) were collected. Lymph node homogenates were assayed by agar gel precipitation test (AGPT), rapid Staphyloccocal protein A (SPA) agglutination test and Dot-ELISA. The overall results revealed that BHV-1 antigens were detected in $43.9 \%, 56.1 \%$ and in $68.4 \%$ of carcass $L n$, and in $29.8 \%, 47.6 \%$ and $57.1 \%$ of visceral $L n$ collected from slaughtered cattle by AGPT, SPA agglutination test and Dot-ELISA respectively. On the other hand, BEFV antigens were detected in $5.3 \%, 38.6 \%$ and $52.6 \%$ of carcass Ln, and in $6 \%, 41.7 \%$ and $54.8 \%$ of visceral Ln collected from slaughtered animals by AGPT, rapid SPA agglutination test and Dot-ELISA respectively. The results showed high percentage of positive samples with SPA agglutination test and DotELISA in comparison to AGPT for both BHV-1 and BEF.
\end{abstract}

Bovine herpesvirus 1 (BHV-1) belongs to subfamily Alphaherpesvirinae of the Herpesviridae. BHV-1 infection can cause conjuncttivitis, pneumonia, genital disorders, abortions, and an upper respiratory infection referred to as shipping fever (Tikoo et al., 1995). BHV-1 was firstly isolated in Egypt, from cattle suffering from respiratory syndrome by Hafez et al., 1974. Infection can occur subclinically. Following an infection with BHV-1, latency of the virus is established and latent virus may be reactivated with stressful condition (Kaashoek et al., 1996). BHV-1 initiates the immunosuppression of infected cattle leading to secondary bacterial infections. Increased susceptibility to secondary infection correlates with depressed cell-mediated immunity after BHV-1 infection (Carter et al., 1989; Griebel et al., 1987a; 1987b and 1990). $\mathrm{CD}^{+}{ }^{+}$T-cell function is impaired during acute infection of calves because BHV-1 infects CD $4^{+}$ $\mathrm{T}$ cells and induces apoptosis (Winkler et al., 1999). Although vaccines are available, they can cause disease in young calves and abortions in cows.

Bovine ephemeral fever virus is a major pathogen for cattle within family Rhabdoviridae characterized by sudden onset of fever, lameness, inappetence, difficult swallowing, serous ocular and nasal discharges, salivation, lameness, and sometimes temporary or permanent paralysis of limbs (Nandi and Negi 1999). The disease was firstly described in Egypt by Rabagliati, 1924, since that time no publications about the occurrence of BEFV in Egypt could be traced until the summer of 1991, where typical form of the disease has been recorded in different governorates (Hassan et al., 1991; Nagi et al., 1992; Banoub, 1994; Hassan, 2000; Zaghawa et al., 2000 and Hamoda, et al., 2002). The present work aims to evaluate the risk prevalence of BHV-1 and BEFV through detection of viral antigens in cattle Ln in BeniSuef governorate.

\section{Material and methods}

Samples. Cattle Ln were collected from clinically normal slaughtered animals at different localities in Beni-Suef governorate as following: a) A total of 114 carcass $\mathrm{Ln}$ represented by portions of prescapular and prefemoral $\mathrm{Ln}$ and $\mathrm{b}$ ) A total 84 of visceral $L n$ represented by portions of left bronchial and posterior mediastinal Ln. Collected samples were prepared as $50 \%$ suspension in phosphate buffer saline $(\mathrm{pH} 7.4)$ and stored at $-20^{\circ} \mathrm{C}$ until used for detection of BHV-1 and BEFV antigens by different immunological tests.

Reference anti-sera and antigens. Reference rabbit anti BHV-1 hyper immune serum and BHV-I antigen were kindly obtained from ELISA unit, animal health research institute 
Dokki, Giza, Egypt. Reference rabbit anti-BEFV hyper immune serum and BEFV antigen were obtained from Virology Dept. Fac. Vet. Med. Beni-Suef, Egypt.

Agar gel precipitation test. AGPT was used for detection of BHV-1 and BEFV antigens in prepared samples using specific reference antisera according to White (1958). Briefly, $6 \mathrm{ml}$ of $1 \%$ agar (Serva, Fein biochemica, Heidelberg, Germany) solution was poured into sterile $60 \mathrm{~mm}$ Petri dishes. After solidification, 7 wells (six peripheral wells surround central one) were made $5.0 \mathrm{~mm}$ in diameter and $3.0 \mathrm{~mm}$ apart. Fifty $\mu \mathrm{l}$ of reference rabbit anti-BHV-1, or rabbit anti-BEFV serum was pipetted into the central well and tested samples were placed in the peripheral ones. Negative and positive control samples were included in each plate. Plates were incubated in humid chamber for 24$72 \mathrm{~h}$ at room temperature and examined for the presence of precipitation lines.

Dot-ELISA. It was used for detection of BHV-1 and BEFV antigens in prepared samples according to (Hawkes et al., 1982). All steps in the Dot-ELISA were done at room temperature. Nitro cellulose membrane (NCM) of convenient size was cut, marked with waterproof ink for identification, and then soaked for $10 \mathrm{~min}$. in distilled water. NCM was laid on absorbent paper and air-dried for $5 \mathrm{~min}$. Three $\mu \mathrm{l}$ of each sample, positive and negative control samples were applied as small spots on the membrane. The dotted membrane was allowed to air dry for $15 \mathrm{~min}$ then incubated for $30 \mathrm{~min}$. in Tris buffer (20 mM Tris base, $500 \mathrm{mM} \mathrm{NaCl} \mathrm{pH} \mathrm{7.5)}$ containing $0.5 \%$ Tween 20 then the blocked membrane was rinsed for $5 \mathrm{~min}$. in Tris buffer. NCM was then incubated for one hour with reference anti-BHV-1, or BEFV predilluted to 1:10 with diluents buffer (Tris buffer containing $0.05 \%$ Tween 20 ), then washed 3 times (10 min. each) with washing buffer. Bound antibodies were detected by incubating NCM for one hour with goat anti-rabbit peroxidase (Sigma, Chemical Co., USA) prediluted to 1:500 with diluent's buffer, then washed 3 times. Finally the membrane was transferred to $60 \mathrm{~mm}$ Petri dish containing $20 \mathrm{ml} \mathrm{4-chloro-1-naphthol} \mathrm{substrate}$ working solution and incubated for $15 \mathrm{~min}$. The membrane was rinsed in water to stop the enzymatic reaction. Blue dots denote positive reaction.

Rapid slide Staphylococcus protein A (SPA) agglutination test. SPA was performed according to (Barrow and Feltham 1995). Five $\mathrm{ml}$ of $10 \%$ SPA suspension (Kindly supplied from immunology unit, reproduction institute, Al-Haram, Giza, Egypt.) was mixed with $5 \mu$ of specific hyper-immune serum. $5 \mu 1$ of prepared tested sample was added to SPA-serum mixture and the slide was rotated for 1-5 min. In positive result, aggregates can be seen by naked eyes and more clear by microscopic examination, while fine sandy ground appears in negative one.

\section{Results and Discussion}

Bovine herpes virus 1 is a member of family Herpesviridae which induces sever economic losses. The source of these losses is not only due to death but also due to weight loss, insufficient feed conversion, abortion, loss of newborn, temporary reduction in body condition and milk yield as well as secondary bacterial bronchopneumonia (Blood et al., 1994 and Madbouly and Abdel-Raof 2004). Although clinical disease induced by BHV-1 can be controlled by vaccination, latent infection often is not prevented (Nettleton et al., 1988 and Kaashoek et al., 1996). As a consequence, animal once infected must be regarded as life long potential shedder of BHV-1. Latency of BHV-1 is a complicated virus-host interaction that plays a crucial role in the pathogenic potential of this virus. BHV-1 establishes latency that is not restricted to ganglionic sensory neurons, typically trigeminal ganglia or sacral dorsal root ganglia but also in non-neural tissues (Mweene et al., 1996; Vogel et al., 2004 and Perez, et al., 2005).

In Egypt, the majority of domestic animal population is not subjected to vaccination for BHV-1. Only small number of private farms used cattle master vaccine for controlling BHV1 and other viral infection. Screening BHV-1 antigens in Ln of slaughtered cattle showed that BHV-1 antigens could be detected in $43.9 \%$, $56.1 \%$ and in $68.4 \%$ of tested carcass Ln by AGPT, rapid SPA agglutination test and DotELISA respectively (Table 1 ). On the other hand, BHV-1 antigens were detected in $29.8 \%$, $47.6 \%$ and in $57.1 \%$ of examined visceral Ln of slaughtered cattle by AGPT, rapid SPA agglutination test and Dot-ELISA respectively (Table 2). This finding is in agreement with many other investigators (Van Englenburge et al., 1994; Mweene et al., 1996; Vogel et al., 2004 and Perez, et al., 2005) who reported additional sites of latency of BHV-1 including animal Ln. The high percentage of BHV-1 in, 
Table (1): Detection of BHV-1 antigens in carcass lymph nodes of slaughtered cattle by AGPT, SPA and Dot-ELISA.

\begin{tabular}{lccccccc}
\hline Locality & Sample & \multicolumn{2}{c}{ AGPT } & \multicolumn{2}{c}{ SPA } & \multicolumn{2}{c}{ Dot-ELISA } \\
\cline { 3 - 8 } & No. & No. of +ve & \%+ve & No. of +ve & \%+ve & No. of +ve & \%+ve \\
\hline EL-Wasta center & 45 & 20 & 44.5 & 26 & 57.8 & 33 & 73.3 \\
Beni-Suef center & 30 & 14 & 46.7 & 18 & 60 & 21 & 70 \\
Somosta center & 39 & 16 & 41 & 20 & 51.3 & 24 & 61.5 \\
Total & 114 & 50 & 43.9 & 64 & 56.1 & 78 & 68.4 \\
\hline
\end{tabular}

Table (2): Detection of BHV-1 antigens in visceral lymph nodes of slaughtered cattle by AGPT, SPA and Dot-ELISA.

\begin{tabular}{lccccccc}
\hline \multirow{2}{*}{ Locality } & Sample & \multicolumn{2}{c}{ AGPT } & \multicolumn{2}{c}{ SPA } & \multicolumn{2}{c}{ Dot-ELISA } \\
\cline { 3 - 8 } & No. & No. of +ve & \%+ve & No. of +ve & \%+ve & No. of +ve & \%+ve \\
\hline EL-Wasta center & 30 & 10 & 33.3 & 16 & 53.3 & 18 & 60 \\
Beni-Suef center & 27 & 8 & 29.6 & 13 & 48.1 & 15 & 55.6 \\
Somosta center & 27 & 7 & 25.9 & 11 & 40.7 & 15 & 55.6 \\
\multicolumn{1}{c}{ Total } & 84 & 25 & 29.8 & 40 & 47.6 & 48 & 57.1 \\
\hline
\end{tabular}

Table (3): Detection of BEFV antigens in carcass lymph nodes of slaughtered cattle by AGPT, SPA and Dot-ELISA.

\begin{tabular}{ccccccccc}
\hline \multirow{2}{*}{ Locality } & Sample & \multicolumn{2}{c}{ AGPT } & \multicolumn{2}{c}{ SPA } & \multicolumn{2}{c}{ Dot-ELISA } \\
\cline { 3 - 8 } & No. & No. of +ve & \%+ve & No. of +ve & \%+ve & No. of +ve & \%+ve \\
\hline EL-Wasta center & 45 & 2 & 4.4 & 17 & 37.8 & 24 & 53.3 \\
Beni-Suef center & 30 & 1 & 3.3 & 9 & 30 & 15 & 50 \\
Somosta center & 39 & 3 & 7.7 & 18 & 46 & 21 & 53.8 \\
\multicolumn{1}{|c}{ Total } & 114 & 6 & 5.3 & 44 & 38.6 & 60 & 52.6 \\
\hline
\end{tabular}

Table (4): Detection of BEFV antigens in visceral lymph nodes of slaughtered cattle by AGPT, SPA and Dot-ELISA.

\begin{tabular}{lccccccc}
\hline \multirow{2}{*}{ Locality } & Sample & \multicolumn{2}{c}{ AGPT } & \multicolumn{2}{c}{ SPA } & \multicolumn{2}{c}{ Dot-ELISA } \\
\cline { 3 - 8 } & No. & No. of +ve & \%+ve & No. of +ve & \% of +ve & No. of +ve & \%+ve \\
\hline EL-Wasta center & 30 & 2 & 6.7 & 12 & 40 & 16 & 53.3 \\
Beni-Suef center & 27 & 1 & 3.7 & 10 & 37 & 14 & 51.9 \\
Somosta center & 27 & 2 & 7.4 & 13 & 48.1 & 16 & 59.2 \\
\multicolumn{1}{c}{ Total } & 84 & 5 & 6 & 35 & 41.7 & 46 & 54.8 \\
\hline
\end{tabular}


the examined samples could be attributed to the ability of this virus to reactivate from latency that is responsible for recurrent disease (Jones 2003 and Perez et al., 2005) and/or increased rate of virus transmission. BHV-1 is transmitted directly by aerosol and by close contact among infected animals e.g. venereally, as well as indirectly via contaminated food and water or through semen in artificial insemination. Interestingly, maternally acquired anti-bodies do not prevent initial viral replication and infection under passive immunity can produce latent infection in sero-negative calves. Cattle once infected with BHV-1, carry latent virus probably for the rest of their live. Latent virus can be reactivated with certain stimuli such as stress factors and consequently excreted with the risk of infecting BHV-1 free herds (Kaashoek et al., 1996; Jones, 2003 and Perez et al., 2005). Therefore in the framework of eradication of BHV-1, cattle once infected with should be detected and culled from the herd. Bovine ephemeral fever is an arthropod-borne viral disease of cattle and water buffaloes characterized by short duration, fever, stiffness, lameness and sometimes paralysis; both onset and recovery are sudden (St George, 1988; Nandi and Negi 1999 and Radostits et al., 2000). The economic importance of the disease may be attributed to drastic drop in milk production, abortion, cost of management and treatment as well as cessations of marketing. Moreover various complications as pneumonia, subcutaneous emphysema, mastitis, hindquarter paralysis and bull infertility for up to 6 months have been reported (Radostits et al., 2000). Screening for BEFV in Ln of slaughtered cattle, revealed the presence of viral antigens in $5.3 \%, 38.6 \%$ and $52.6 \%$ of tested carcass Ln by AGPT, rapid SPA agglutination test and DotELISA respectively (Table 3 ). On the other hand, data presented in (Table 4) showed that BEFV antigens were detected in $6 \%, 41.7 \%$ and in $54.8 \% \%$ of tested visceral Ln by AGPT, rapid SPA agglutination test and Dot-ELISA respectively. These findings agree with the fact that BEFV replicate in reticuloendothelial cells in lungs, spleen and lymph nodes (St George, 1988) and BEFV infection results in oedema and enlargement of most animal lymph nodes (Radostits et al., 2000; Hamoda et al., 2002 and Zaghawa, 2002). The high incidence of BEFV in Egyptian cattle may be attributed to the widespread of flying insect vectors (mosquito species) that are responsible for transmission of the disease mainly during rainy and warm seasons, therefore BEFV control programs should include eradication of arthropod vectors. Interestingly, carcass Ln showed relatively higher positive percentage of BHV-1 than visceral $\mathrm{Ln}$, while no differences was detected in case of BEFV.

The results in (Table 1-4) showed lower sensitivity of AGPT, in comparison to higher sensitivity of rapid SPA agglutination test and higher sensitivity of Dot-ELISA. AGPT in spite of its specificity, is recorded to be of low sensitivity (Van Kammen and Spradbrow 1976) and its result is variable; a fact rendered AGPT negative samples should be retested by another immunological tests. Dot-ELISA and SPA have been adopted for use in detecting antigens to a variety of disease causing agents. The use of either Dot-ELISA or SPA offer a number of advantages compared with traditional immunological assays; including increased sensitivity and high specificity. (Hawkes et al., 1982; Bennette and Yeoman 1983; Furui, 1986 and Khaustav et al., 1988). The advantage of rapid SPA agglutination test lies on its rapidity, sensitivity, easily performed hence it can be used in screening large number of samples at short time. Dot-ELISA is also rapid, inexpensive and relatively high specific test. These facts render them preferred tests for detection viral antigens in clinical samples.

From all previously mentioned results we could conclude that BHV-1 and BEFV constitute real challenges to cattle health and production in Egypt, a fact that necessitates increased effort to control such viruses by suitable strict regulations and control measures.

\section{References}

Banoub, S. M. (1994): Ephemeral fever (three day sickness) in closed milking cow farm at Sharquia $6^{\text {th }}$ Sci. Cong. Fac. Vet. Med. Assiut, Egypt, pp.558-563.

Barrow, G. I. and Feltham, R. K. A. (1995): Cowan steels manual for the identification of medical bacteria $3^{\text {rd }}$ ed. Cambridge University press, Great Britain.

Bennette, T. F. C. and Yeoman, L. C. (1983): An improved procedure for the Dot immunobinding analysis of hybridoma supernatant. J.Immunol.Method., 61: 201-207.

Blood, A.; Radositit, O. M. and Hendersan, J. A. (1994): Veterinary Medicine, A text book of disease of domestic animals $8^{\text {th }}$ ed. Eibs and Balliere Tindal, England.

Carter, J. J.; Weinberg, A. D.; Pollard, A.; Reeves, R.; Magnuson, J. A. and Magnuson, N. S. (1989): Inhibition of T-lymphocyte mitogenic responses and effects on cell functions by bovine herpesvirus 1. J. Virol., 63:1525-1530. Furui, S. (1986): Use of protein $A$ in the serum in agar diffusion method in immune-electron microscope for 
detection of virus particles in cell culture. Microbiol. Immunol., 30 (10):1023-1035.

Griebel, P. J.; Ohmann, H. B.; Lawman, M. J. and Babiuk, L. A. (1990): The interaction between bovine herpesvirus type 1 and activated bovine T lymphocytes. J. Gen. Virol., 71: 369-377.

Griebel, P. J.; Qualtiere, L.; Davis, W. C.; Gee, A.; Bielefeldt Ohmann, H.; Lawman, M. J. and Babiuk, L. A. (1987a): $T$ lymphocyte population dynamics and function following a primary bovine herpesvirus type-1 infection. Viral Immunol., 1:287-304.

Griebel, P. J.; Qualtiere, L.; Davis, W. C.; Lawman, M. J. and Babiuk, L. A. (1987b): Bovine peripheral blood leukocyte subpopulation dynamics following a primary bovine herpesvirus-1 infection. Viral Immunol., 1:267-286. Hafez, S. M.; Baz,T. I.; Zharan, M. and Ahamed, Y. A. (1974): Isolation and identification of infectious pustular vulvovaginitis from local cattle and buffoloes in Egypt. J. Egyp. Vet. Med. Assoc., 38 (4): 45-53.

Hamoda, F. K.; Khalaf-Allah, S. S. and Khodeir, M. H. (2002): Some clinical, epidemiological and laboratory studies on bovine ephemeral fever (three days sickness). Vet. Med. J. Giza, 2: 203-220.

Hassan, H. B.; EL-Danaf, N. A.; Hafez, M. A. M.; Ragab, A. M. and Mohamed, F.M. (1991): Clinicodiagnostic studies on bovine ephemeral fever with detection of the virus for first time in Egypt. J. Egyp. Vet. Med. Assoc., 51 (4): 873-887.

Hassan, H. Y. (2000): An outbreak of bovine ephemeral fever in Egypt during $20009^{\text {th }}$ Sci. Cong. Fac. Vet. Med. Assiut Univ., Egypt, 325-336.

Hawkes, R.; Niday, E. and Gordan, J. (1982): A dotimmunobinding assay for monoclonal and other antibodies. Anal. Biochem., 119:142-147.

Jones, C. 2003. Herpes simplex virus type 1 and bovine herpesvirus 1 latency. Clin. Microbiol. Rev., 16: 79-95.

Kaashoek, M. J.; Rijsewijk, F. M. A. and Van Oirschot, J. T. (1996): Persistence of antibodies against bovine herpesvirus 1 and virus reactivation two to three years after infection. Vet. Microbiol., 53:103-110.

Khaustov, V. I.; Shokoian, L. A.; Drozdov, S. G. and Kralov, M. B. (1988): A method of solid phase analysis of antigens using Staphylococcus aureus as the label. Vopr. Virusol., 33: 1996-200.

Madbouly, H. M. and Abdel-Raof, A. (2004): Risk of BHV-1 infection in some domestic animals in Egypt. Egyp. Soc. Anim. Rep. Fert. $16^{\text {th }}$ Annual Cong., pp. 243252.

Mweene A. S.; Okazaki, K. and Kida, H. (1996): Detection of viral genome in non-neural tissues of cattle experimentally infected with bovine herpesvirus 1 . Jap. .J. Vet Res., 44:165-174.

Nagi, A. A.; Elmashed, A. I.; Elbagaury, G. F. and Moustfa, A. M. (1992): An investigation on ephemeral fever (three day sickness) in cattle at Kalyubia governorate (Egypt). Annual Agric. Sci. Moshtohar, Egypt, 30 (2): 1159-1169.

Nandi, S. and Negi, B. S. (1999): Bovine ephemeral fever. Comp. Immunol. Microbiol. Infect. Dis., 22:81-91.

Nettleton, P. F.; Thiry, E.; Reid, H. and Postaret, P. (1988): Herpesvirus infections in Cervidae. Rev. Sci. Tech. Aff. Int. Epiz., 7: 977-988.

Perez S.; Inman, M.; Doster, A. and Jones, C. (2005): Latency-related gene encoded by bovine herpesvirus 1 promotes virus growth and reactivation from latency in tonsils of infected calves. J. Clin. Microbiol., 43:393-401.

Rabagliati, D. S. (1924): Three days fever or stiff sickness in cattle. Vet. Rec., 33: 503-505.

Radostits, O. M.; Gay, G. C.; Blood, D.C. and Hincheliff, K. (2000): Veterinary Medicine A text book of the diseases of cattle, sheep, pigs, goats and horses $9^{\text {th }}$ ed. W.B. Sounders Company Ltd.

St George, T.D. (1988): Bovine ephemeral fever. Trop. Anim. Health. Prod., 20: 194-202.

Tikoo, S. K.; Campos, M. and Babiuk, L. A. (1995): Bovine herpesvirus 1 (BHV-1): biology, pathogenesis, and control. Adv. Virus Res., 45:191-223.

Van Engelenburge, F. A.; Kaashaek, M. J.; Van Airschot, J. T. and Rijsewijk, F. A. M. (1994): A glycoprotein E deletion mutant of bovine herpes of tissue in calves as wild - type virus but for shorter period. Vet. Med. Thesis (F.A.C. Van Engelenburge). Utrecht, Univ., The Netherlands, pp. 33-50.

Van Kammen, A. and Spradbrow, P. B. (1976): Rapid diagnosis of some avian viruses. Avian Dis., 20: 748-751.

Vogel, F. S.; Flores, E. F.; Weiblen, R.; Winkelmann, E. R.; Moraes, M. P. and Braganca, J. F. (2004): Intrapreputial infection of young bulls with bovine herpesvirus type 1,2 (BHV-1,2): acute balanoposthitis, latent infection and detection of viral DNA in regional neural and non-neural tissues 50 days after experimental reactivation. Vet. Microbiol. 98: 185-196.

White, G. (1958): The agar diffusion precipitation reaction for R.P report of the east Afr. Vet.Res.Org. 1956. 57: 2232.

Winkler, M. T.; Doster, A. and Jones, C. (1999): Bovine herpesvirus 1 can infect CD4(+) T lymphocytes and induce programmed cell death during acute infection of cattle. J. Virol., 73:8657-8668.

Zaghawa, A. (2002): Bovine ephemeral fever (three days sickness). Minufiya Vet. J. $2^{\text {nd }}$ Vet. Cong. Egypt, pp. 345360 .

Zaghawa, A., Akla, M. A.; Khader, A. M and Hassan, H. Y. (2000): An outbreak of bovine ephemeral fever in Egypt during 2000. Clinical and Epidemiological Investigation $9^{\text {th }}$ Sci. Cong. Fac. Vet. Med. Assiut Univ., Egypt, pp.346-353. 